\title{
Effects of adenosine stimulation on the mRNA expression of CLCNKB in the basolateral medullary thick ascending limb of the rat kidney
}

\author{
HAIYAN LUAN ${ }^{1,2}$, PENG WU ${ }^{1}$, MINGXIAO WANG ${ }^{1}$, HONGYU SUI $^{2}$, LILI FAN $^{1}$ and RUIMIN GU ${ }^{1}$ \\ ${ }^{1}$ Department of Pharmacology, Harbin Medical University, Harbin, Heilongjiang 150081; \\ ${ }^{2}$ Department of Physiology, Basic Medical School, Jiamusi University, Jiamusi, \\ Heilongjiang 154007, P.R. China
}

Received August 31, 2015; Accepted August 6, 2016

DOI: $10.3892 / \mathrm{mmr} .2016 .5781$

\begin{abstract}
Adenosine is a molecule produced by several organs within the body, including the kidneys, where it acts as an autoregulatory factor. It mediates ion transport in several nephron segments, including the proximal tubule and the thick ascending limb (TAL). Ion transport is dictated in part by anionic chloride channels, which regulate crucial kidney functions, including the reabsorption of $\mathrm{Na}^{+}$and $\mathrm{Cl}^{-}$, urine concentration, and establishing and maintaining the corticomedullary osmotic gradient. The present study investigated the effects of adenosine on the mRNA expression of chloride voltage-gated channel $\mathrm{Kb}(C L C N K B)$, a candidate gene involved in hypertension, which encodes for the $\mathrm{ClC}-\mathrm{Kb}$ channel. Medullary thick ascending limb (mTAL) tubules were isolated from the rat kidney, and primary cultures of mTAL cells from the mTAL tubules were established. The cells were treated with adenosine and the mRNA expression of $C L C N K B$ was detected by reverse transcription-quantitative polymerase chain reaction. The cells were also treated with pathways inhibitors (H8 and AACOCF3), and the protein expression of cyclic adenosine 3',5'-monophosphate (cAMP)-protein kinase $\mathrm{A}$ (PKA) and phospholipase $\mathrm{A}_{2}\left(\mathrm{PLA}_{2}\right)$ by were analyzed by western blotting. The findings indicated that adenosine increased the mRNA expression of $C L C N K B$ in primary cultures of medullary TAL cells, and this stimulatory effect was regulated by the cAMP-PKA and PLA $\mathrm{A}_{2}$-arachidonic acid (AA) pathways. The present study showed that adenosine affected the mRNA expression of $C L C N K B$, initially through the cAMP-PKA pathway and then the $\mathrm{PLA}_{2}$-AA pathway.
\end{abstract}

Correspondence to: Professor Ruimin Gu, Department of Pharmacology, Harbin Medical University, 157 Baojian Road, Harbin, Heilongjiang 150081, P.R. China

E-mail: ruimingu2916@163.com

Key words: adenosine, chloride voltage-gated channel $\mathrm{Kb}$, protein kinase $\mathrm{A}_{2}$, phospholipase $\mathrm{A}_{2}$

\section{Introduction}

The kidney is crucial in maintaining homeostasis within the body by regulating the excretion of water and electrolytes according to the requirements of the body. The maintenance of homeostasis by the kidney is controlled at the neural and humoral levels, however, it is also mediated through autoregulation, which has a critical effect on function. The kidney can produce a multitude of local, active substances, including adenosine triphosphate, adenosine and angiotensin II (1-7).

Previous studies have shown that, in addition to cardiac and skeletal muscle undergoing autoregulation by adenosine, kidney function may be controlled in the same manner (8-10). Under physiological conditions, adenosine has been shown to control the release of renin (11-13), renal blood flow, glomerular filtration rate (14), glomerulotubular balance and tubuloglomerular feedback $(15,16)$. It is also involved in regulating ion transport in several nephron segments, including the proximal tubule and the thick ascending limb (TAL) $(6,14,17-19)$.

The degree of $\mathrm{NaCl}$ transport has a direct effect on the formation of the renal medulla hypertonic gradient, which ultimately affects urine dilution and concentration. Furthermore, $\mathrm{NaCl}$ transport is affected significantly by chloride channel activity. Our previous studies showed that arachidonic acid (AA), a local and active substance, inhibits the activities of potassium and chloride channels. Additionally, adenosine was found to affect the activity of potassium channels in the medullary TAL (mTAL). Thus, elucidating the regulatory mechanism of adenosine on chloride channels has the potential not only to improve current understanding of $\mathrm{Na}^{+}, \mathrm{K}^{+}$and $\mathrm{Cl}^{-}$transport in the mTAL, but also offers novel insights for developing high performance diuretics and therapies for the clinical treatment of hypertension. The current study investigated the effects of adenosine stimulation on the expression of $C L C N K B$ mRNA in the basolateral mTAL of the rat kidney, and the pathways involved in th effects. This study provides insight into the regulation and mechanisms of kidney function, and a potential new target for the clinical treatment of kidney disease. 


\section{Materials and methods}

Animals. Pathogen-free Sprague-Dawley rats (male and female; 50-60 g; $\mathrm{n}=20$ ) were obtained from the Animal Center of the Second Affiliated Hospital of Harbin Medical University (Harbin, China) and were maintained with standard rat chow and access to tap water ad libitum. The study was approved by the ethics committee of Harbin Medical University.

Isolation of mTAL tubules and cells. The method for the preparation of mTAL suspensions was established on the basis of the methods described in several previous studies (20-22). The rats were sacrificed by cervical dislocation and the kidneys were removed immediately for future dissection of the mTAL cells. The inner stripe of the outer medulla was carefully excised and minced with a sterile blade. It was then sequentially incubated and shaken at $37^{\circ} \mathrm{C}$ in HEPES buffer solution containing $0.01 \%$ collagenase type IA $(1 \mathrm{mg} / \mathrm{ml}$; Sigma-Aldrich; Thermo Fisher Scientific, Inc., Walthlam, MA, USA) and $140 \mathrm{mM} \mathrm{NaCl}, 5 \mathrm{mM} \mathrm{KCl}, 1.8 \mathrm{mM} \mathrm{MgCl}_{2}, 1.8 \mathrm{mM}$ $\mathrm{CaCl}_{2}$ and $10 \mathrm{mM}$ HEPES (pH 7.4) for $5 \mathrm{~min}$. The suspension was precipitated on ice, and then mixed with HEPES buffer solution again. Finally, the supernatant containing the crude suspension of tubules was collected. The undigested tissues were subjected to three treatments with collagenase (5 min each), and the combined supernatants were suspended in HEPES buffer solution and then filtered through 180 and $50 \mu \mathrm{m}$ nylon mesh membranes. The tubules retained on the $50 \mu \mathrm{m}$ mesh were collected with centrifugation $(1,000 \times \mathrm{x}$, $5 \mathrm{~min}, 4^{\circ} \mathrm{C}$ ) and suspended in HEPES buffer solution. The suspension, which contained the mTAL tubules, was used to establish primary cultures of mTAL cells. The mTAL tubules $\left(5 \times 10^{5} / \mathrm{ml}\right)$ were cultured at $37^{\circ} \mathrm{C}$ in $90-\mathrm{mm}$-diameter Petri dishes using Renal Epithelial Cell culture medium (Dulbecco's modified Eagle's medium/F12; 1:1; Hyclone; GE Healthcare Life Sciences, Logan, UT, USA), which contained $10 \%$ fetal bovine serum (Gibco; Thermo Fisher Scientific, Inc.), $1 \%$ streptomycin-penicillin $(100 \mathrm{U} / \mathrm{ml})$, rhEGF (Peprotech, Inc., Rocky Hill, NJ, USA), insulin, hydrocortisone, amphotericin B and epinephrine (Nanjing KGI Biological Technology Development Co., Ltd., Nanjing, China). After 6-7 days, the monolayer of cells was $80-90 \%$ confluent, and used in the subsequent experiments.

Cell treatments. When the cells were in the logarithmic growth phase, the medium was changed to serum-free medium. Initially, $25.6 \mu \mathrm{M}$ adenosine was added to the cells and incubated for $6,12,24$ and $48 \mathrm{~h}$ to find the greatest effect time. Subsequently, different concentrations of adenosine (1.6, $3.2,6.4,12.8,25.6$ and $51.2 \mu \mathrm{M}$ ) were added to indicate the best concentration to use. The mRNA expression of $C L C N K B$ was analyzed using the chosen duration and concentration of adenosine treatment. Finally, $5 \mu \mathrm{M}$ AACOCF3 or $5 \mu \mathrm{M}$ $\mathrm{H} 8$ were used to treat cells for $6 \mathrm{~h}$, then $25.6 \mu \mathrm{M}$ adenosine was added $24 \mathrm{~h}$ to determine whether the cAMP-PKA and PLA2-AA pathways affected the mRNA expression of $C L C N K B$ in the presence of adenosine.

Western blot analysis. When the cells were in logarithmic growth phase, the medium was completely removed, the cells were washed twice in ice-cold PBS and lysed with $400 \mu \mathrm{l}$ cell lysis buffer (1\% sodium deoxycholate; $10 \mathrm{mM}$ Tris-Cl, $\mathrm{pH} \mathrm{8;}$ $1 \mathrm{nM}$ EDTA-Na, $\mathrm{pH}$ 8; $0.5 \mathrm{mM}$ PMSF; $1.5 \mu \mathrm{M}$ aprotinin; $154 \mathrm{nM}$ pepstatin; $50 \mu \mathrm{M}$ phloroglucinol) per dish. Cells were scraped off the dish and transferred into eppendorf tubes, and maintained on ice for $15 \mathrm{~min}$. The samples were sonicated for 3-5 sec. Protein concentrations were determined by bicinchoninic acid assay (Thermo Fisher Scientific, Inc.) The protein samples $(50 \mu \mathrm{g})$ from the primary cultures of mTAL cells were separated by electrophoresis using 10\% SDS-PAGE and transferred onto nitrocellulose membranes (Pall Life Sciences, Port Washington, NY, USA). The membranes were blocked with $5 \%$ nonfat dry milk in $0.1 \%$ Tween-Tris-buffered saline (TBS-T), and then washed with $0.1 \%$ TBS-T. The membranes were incubated with primary antibody overnight at $4^{\circ} \mathrm{C}$ (rabbit anti-rat $\mathrm{cPLA}_{2}, 1: 1,000$; rabbit anti-rat PKA, 1:1,000; rabbit anti-rat $\beta$-actin, 1:1,000). Following incubation, the membranes were washed four times (10 min per wash) with $0.1 \%$ TBS-T, following which the membranes were incubated with horseradish peroxidase-conjugated goat anti-rabbit secondary antibody (1:10,000; OriGene Technologies, Inc., Rockville, MD, USA) for $1 \mathrm{~h}$ at room temperature. SuperSignal West Pico Chemiluminescent Substrate (Pierce; Thermo Fisher Scientific, Inc.) was used to detect the protein bands. The protein bands were quantified by densitometry using Quantity One software (Bio-Rad Laboratories, Inc., Hercules, CA, USA).

Reverse transcription-polymerase chain reaction (RT-PCR) analysis. Total RNA was purified from the primary cultures of the mTAL cells in the logarithmic growth phase using a Protein and RNA Extraction kit for mammalian cells (Takara Biotechnology Co., Ltd., Dalian, China). RNA was then quantified using spectrophotometry and reverse transcribed into cDNA using RT-PCR kit (Takara Biotechnology Co., Ltd.). The cDNA was amplified using a master mix containing Taq polymerase (Takara Biotechnology Co., Ltd.) and the following primers from AuGCT DNA-SYN Biotechnology Co., Ltd. (Beijing, China): CLCNKB, sense 5'-CTGTTCCGT GTGGGTGAG-3' and antisense 5'-GGGTACACGGTCCAA GAG-3'; $\beta$-actin, sense 5'-AGATCCTGACCGAGCGTGGC-3' and antisense 5'-CCAGGGAGGAAGAGGATGCG-3'. Each primer was used at a final concentration of $20 \mu \mathrm{M}$. The thermocycling steps were as follows: $\beta$-actin; $94^{\circ} \mathrm{C}$ for $5 \mathrm{~min}$, then $94^{\circ} \mathrm{C}$ for $30 \mathrm{sec}, 56^{\circ} \mathrm{C}$ annealing for $30 \mathrm{sec}$ and $72^{\circ} \mathrm{C}$ extension for $25 \mathrm{sec}\left(25\right.$ cycles), and $72^{\circ} \mathrm{C}$ for $7 \mathrm{~min}$; CLCNKB: $94^{\circ} \mathrm{C}$ for $5 \mathrm{~min}$, then $94^{\circ} \mathrm{C}$ for $30 \mathrm{sec}, 56^{\circ} \mathrm{C}$ annealing for $30 \mathrm{sec}$, $72^{\circ} \mathrm{C}$ extension for $25 \mathrm{sec}$ ( 40 cycles), and $72^{\circ} \mathrm{C}$ for $7 \mathrm{~min}$ The PCR products were separated on a $3 \%$ agarose gel and stained with ethidium bromide to identify fragments of $C L C N K B$ and $\beta$-actin. The gene fragments were quantified by densitometry using Quantity One software (Bio-Rad Laboratories, Inc.).

Chemicals. The antibodies for $\beta$-actin (cat. no. sc-7210), PKA (cat. no. sc-28892) and cPLA 2 (cat. no. sc-438) were obtained from Santa Cruz Biotechnology, Inc. (Dallas, TX, USA). Reagent-grade chemicals, adenosine, AACOCF3 (an antagonist of $\mathrm{PLA}_{2}$ ) and $\mathrm{H} 8$ (an antagonist of PKA) were obtained from Sigma-Aldrich; Thermo Fisher Scienfiic, Inc. The prestained protein ladder was obtained from Fermentas; Thermo Fisher Scientific, Inc. 

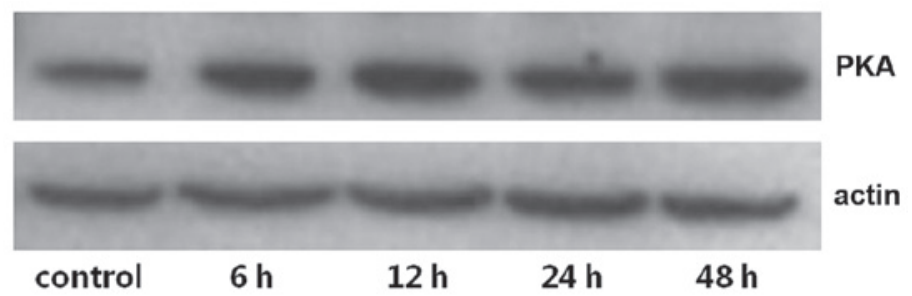

Figure 1. Effects of adenosine $(25.6 \mu \mathrm{M})$ on the expression of PKA in the primary cultures of medullary thick ascending limb cells. Expression of PKA was determined via western blot analysis. PKA, protein kinase A.

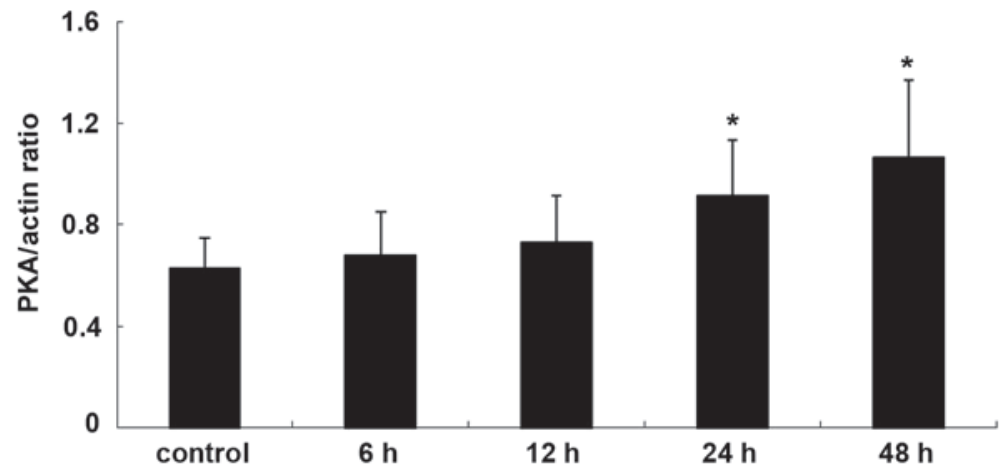

Figure 2. Effects of adenosine $(25.6 \mu \mathrm{M})$ on the expression of PKA in the primary cultures of medullary thick ascending limb cells. Data are presented as the mean + standard deviation $(\mathrm{n}=3)$. ${ }^{*} \mathrm{P}<0.05$, vs. control group. PKA, protein kinase $\mathrm{A}$.

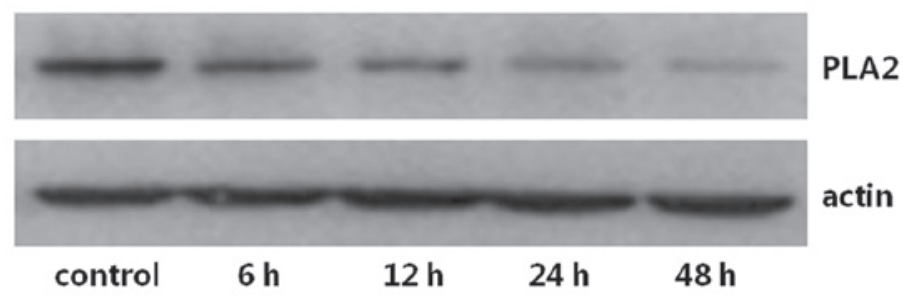

Figure 3. Effects of adenosine $(25.6 \mu \mathrm{M})$ on the expression of $\mathrm{PLA}_{2}$ in the primary cultures of medullary thick ascending limb cells. Expression was detected using western blot analysis. PLA 2 , phospholipase $\mathrm{A}_{2}$.

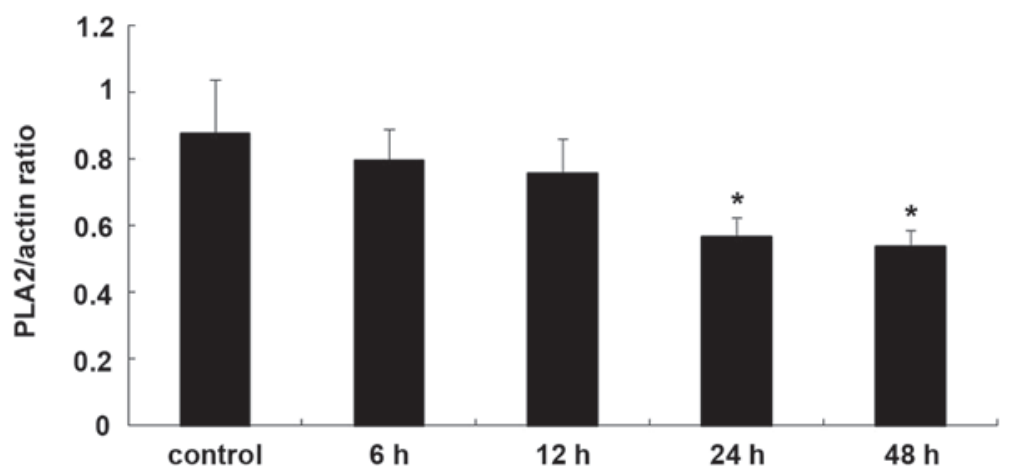

Figure 4. Effects of adenosine $(25.6 \mu \mathrm{M})$ on the expression of $\mathrm{PLA}_{2}$ in the primary cultures of medullary thick ascending limb cells. Data are presented as the mean + standard deviation $(\mathrm{n}=3)$. ${ }^{*} \mathrm{P}<0.05$, vs. control group. $\mathrm{PLA}_{2}$, phospholipase $\mathrm{A}_{2}$.

Statistical analysis. Data are shown as the mean \pm standard deviation. Paired Student's $t$-tests were used to determine the significance of differences between the control and experimental groups. $\mathrm{P}<0.05$ was considered to indicate a statistically significant difference.

\section{Results}

Expression levels of PKA and $\mathrm{PLA}_{2}$ in primary cultures of mTAL cells. Upon adenosine binding to its receptors, target cells are typically affected through the activation or inhibition 


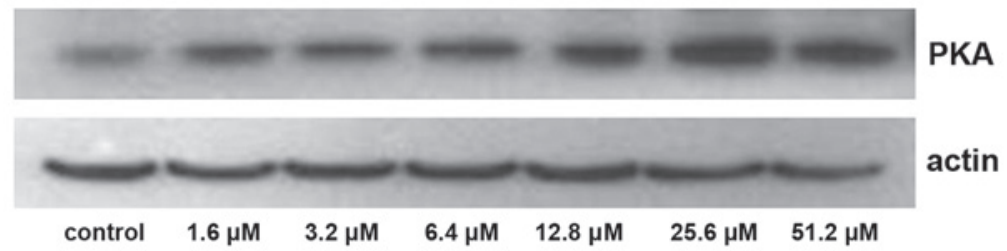

Figure 5. Effects of adenosine ( $24 \mathrm{~h})$ on the expression of PKA in the primary cultures of medullary thick ascending limb cells. Expression was detected using western blot analysis. PKA, protein kinase A.

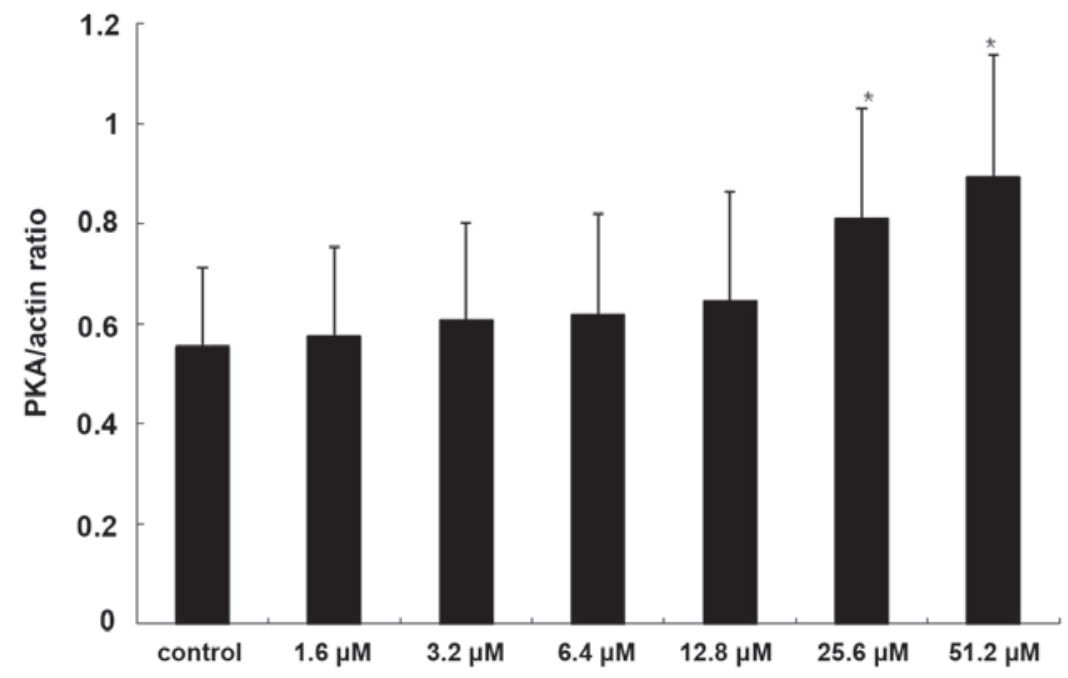

Figure 6. Effects of adenosine ( $24 \mathrm{~h})$ on the expression of PKA in the primary cultures of medullary thick ascending limb cells. Data are presented as the mean + standard deviation $(n=3) . ~{ }^{*} \mathrm{P}<0.05$, vs. control group. PKA, protein kinase A.

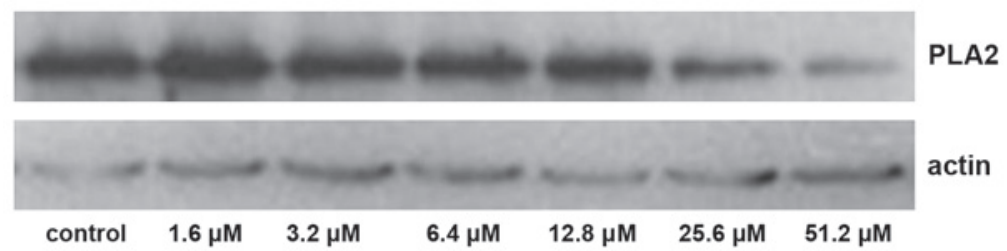

Figure 7. Effects of adenosine $(24 \mathrm{~h})$ on the expression of $\mathrm{PLA}_{2}$ in the primary cultures of medullary thick ascending limb cells. Expression was detected using western blot analysis. PLA 2 , phospholipase $\mathrm{A}_{2}$.

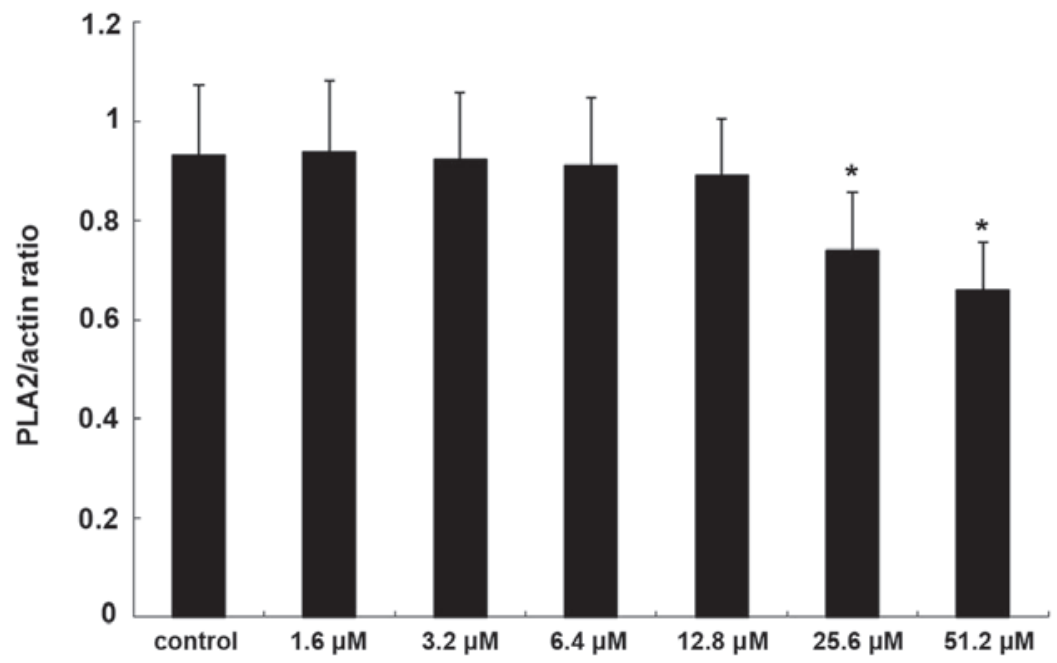

Figure 8. Effects of adenosine $(24 \mathrm{~h})$ on the expression of $\mathrm{PLA}_{2}$ in the primary cultures of medullary thick ascending limb cells. Data are presented as the mean + standard deviation $(n=3)$. ${ }^{*} P<0.05$, vs. control group. PLA $A_{2}$, phospholipase $A_{2}$. 

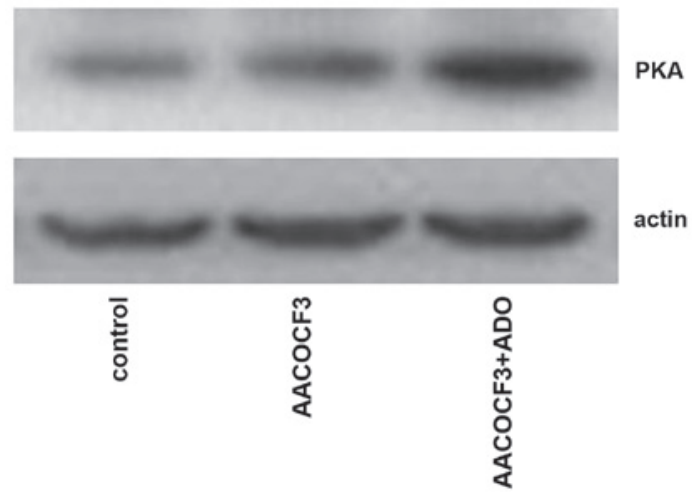

Figure 9. Effects of adenosine $(25.6 \mu \mathrm{M})$ on the expression of PKA in the primary cultures of medullary thick ascending limb cells pretreated with AACOCF3 $(5 \mu \mathrm{M})$. Expression was detected using western blot analysis. PKA, protein kinase A; ADO, adenosine.

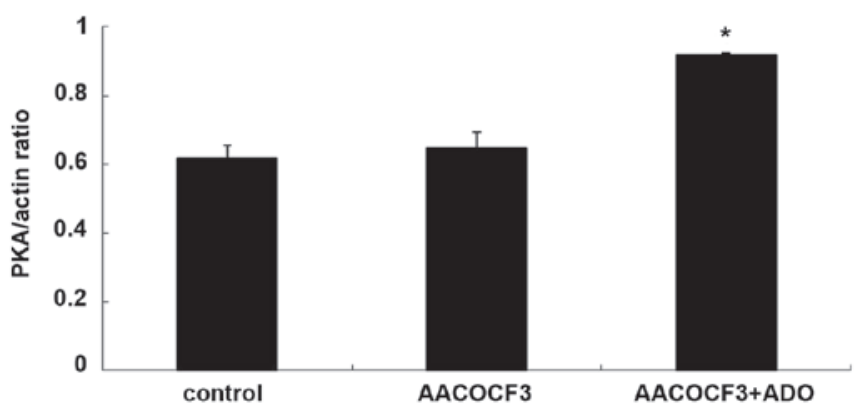

Figure 10. Effects of adenosine $(25.6 \mu \mathrm{M})$ on the expression of PKA in the primary cultures of medullary thick ascending limb cells pretreated with AACOCF3 $(5 \mu \mathrm{M})$. Data are presented as the mean + standard deviation $(n=3) .{ }^{*} \mathrm{P}<0.05$, vs. control group. PKA, protein kinase A; ADO, adenosine.
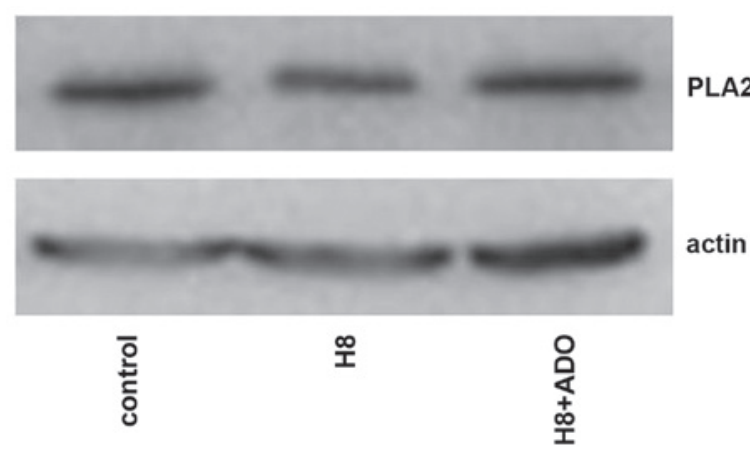

Figure 11. Effects of adenosine $(25.6 \mu \mathrm{M})$ on the expression of PLA $\mathrm{P}_{2}$ in the primary cultures of medullary thick ascending limb cells pretreated with $\mathrm{H} 8$ $(5 \mu \mathrm{M})$. Expression was detected using western blot analysis. $\mathrm{PLA}_{2}$, phospholipase $\mathrm{A}_{2}$.

of the cyclic adenosine monophosphate-protein kinase A (cAMP-PKA), phospholipase $\mathrm{A}_{2}$-arachidonic acid ( $\mathrm{PLA}_{2}$-AA) and phospholipase C-protein kinase $\mathrm{C}$ pathways (23). The expression levels of PKA and $\mathrm{PLA}_{2}$ in primary cultures of mTAL cells were determined using western blot analysis. The expression levels of PKA and PLA $_{2}$ were detected over time and in the presence of increasing concentrations of adenosine. Compared with the control group, the expression of PKA increased significantly at 24 and $48 \mathrm{~h}$ post-adenosine

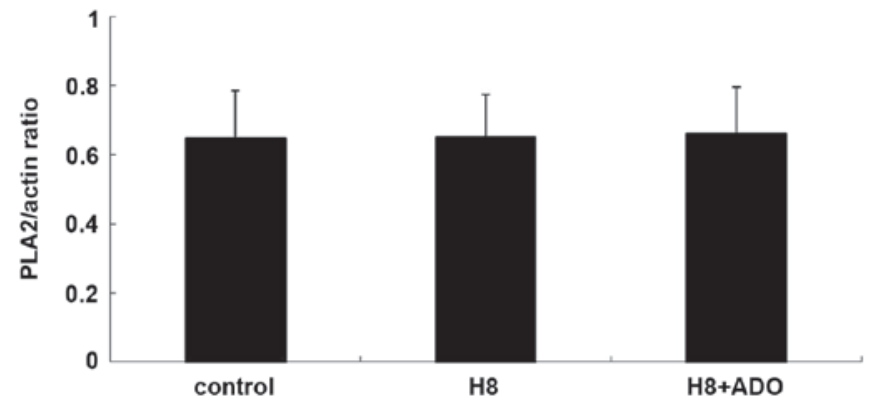

Figure 12. Effects of adenosine $(25.6 \mu \mathrm{M})$ on the expression of $\mathrm{PLA}_{2}$ in the primary cultures of medullary thick ascending limb cells, which were pretreated with $\mathrm{H} 8(5 \mu \mathrm{M})$. Data are presented as the mean + standard deviation $(\mathrm{n}=3)$. PLA $\mathrm{A}_{2}$, phospholipase $\mathrm{A}_{2}$.

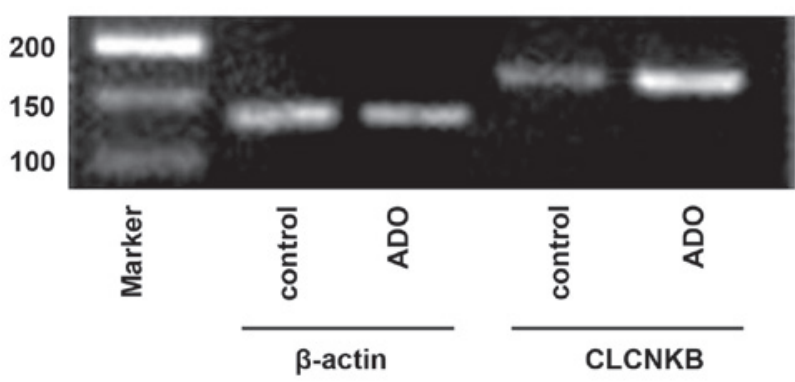

Figure 13. Effects of adenosine $(25.6 \mu \mathrm{M} ; 24 \mathrm{~h})$ on the mRNA expression of $C L C N K B$ in the primary cultures of medullary thick ascending limb cells Expression was detected using reverse transcription-polymerase chain reaction analysis. $\beta$-actin was used as a positive control. Ethidium bromide was used to observe the products for $C L C N K B$ (173 bp) and $\beta$-actin (138 bp). $C L C N K B$, chloride voltage-gated channel $\mathrm{Kb}$; $\mathrm{ADO}$, adenosine.

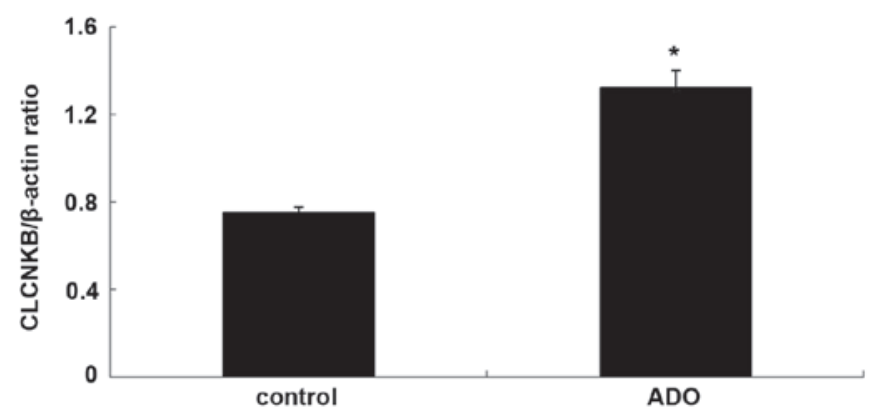

Figure 14. Effects of adenosine $(25.6 \mu \mathrm{M}, 24 \mathrm{~h})$ on the mRNA expression of $C L C N K B$ in the primary cultures of medullary thick ascending limb cells. Data are presented as the mean + standard deviation $(n=3) .{ }^{*} \mathrm{P}<0.05$, vs. control group. $C L C N K B$, chloride voltage-gated channel $\mathrm{Kb}$; $\mathrm{ADO}$, adenosine.

treatment $(\mathrm{P}<0.05$; Figs. 1 and 2$)$, whereas the expression of $\mathrm{PLA}_{2}$ decreased significantly at 24 and $48 \mathrm{~h}$ post-adenosine treatment $(\mathrm{P}<0.05$; Figs. 3 and 4$)$. No change was observed at 6 or $12 \mathrm{~h}$.

The expression of PKA increased significantly following treatment with 25.6 and $51.2 \mu \mathrm{M}$ adenosine $(\mathrm{P}<0.05$; Figs. 5 and 6), whereas the expression of $\mathrm{PLA}_{2}$ decreased significantly following treatment with 25.6 and $51.2 \mu \mathrm{M}$ adenosine $(\mathrm{P}<0.05$; Figs. 7 and 8$)$.

Interaction of the CAMP-PKA and PLA $-A A$ pathways. As shown in Figs. 9 and 10, adenosine treatment significantly 


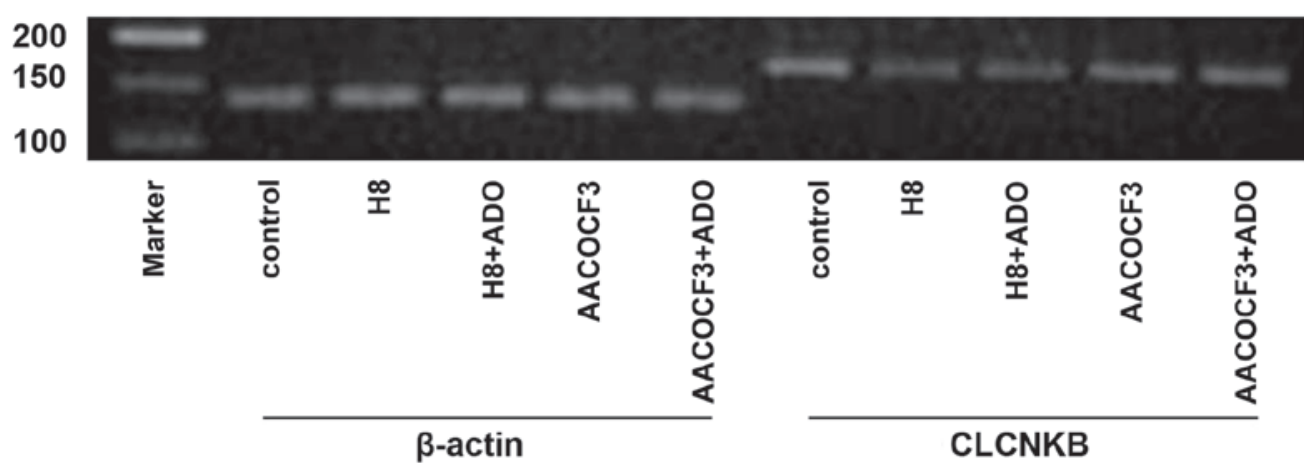

Figure 15 . Effects of adenosine $(25.6 \mu \mathrm{M}, 24 \mathrm{~h})$ on the mRNA expression of CLCNKB following H8 and AACOCF3 treatments in the primary cultures of medullary thick ascending limb cells. Expreesion was detected using reverse transcription-polymerase chain reaction analysis. $\beta$-actin was used as a positive control. Ethidium bromide was used to observe the products for CLCNKB (173 bp) and $\beta$-actin (138 bp). CLCNKB, chloride voltage-gated channel Kb; ADO, adenosine.

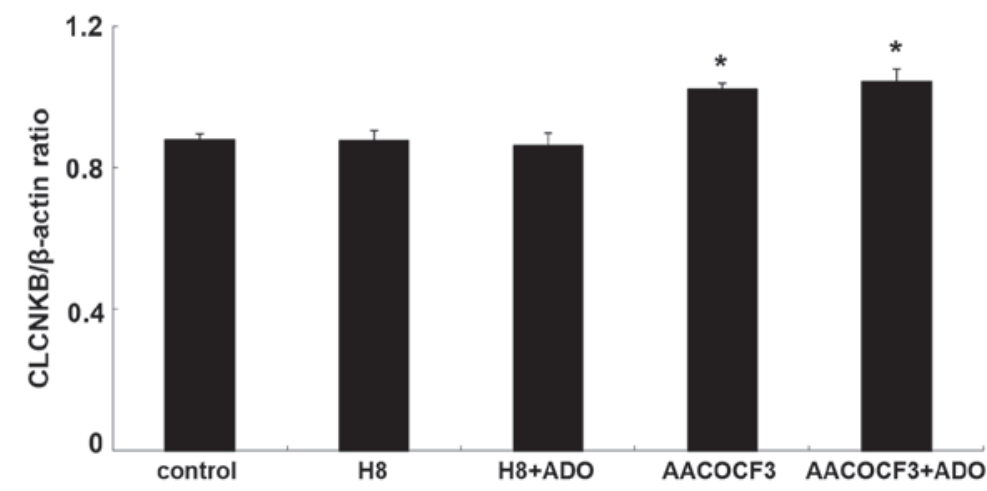

Figure 16. Effects of adenosine $(25.6 \mu \mathrm{M} ; 24 \mathrm{~h})$ on the mRNA expression of $C L C N K B$ following H8 and AACOCF3 treatments in the primary cultures of medullary thick ascending limb cells. Data are presented as the mean + standard deviation $(\mathrm{n}=3)$. ${ }^{*} \mathrm{P}<0.05$, vs. control group. $C L C N K B$, chloride voltage-gated channel $\mathrm{Kb}$.

increased the expression of PKA in primary cultures of mTAL cells $(\mathrm{P}<0.05)$, which were pretreated with AACOCF3 for $6 \mathrm{~h}$ prior to treatment with adenosine for $24 \mathrm{~h}$. However, as shown in Figs. 11 and 12, adenosine treatment did not alter the expression of $\mathrm{PLA}_{2}$ in the primary cultures of the mTAL cells, which had been pretreated with $\mathrm{H} 8$ for $6 \mathrm{~h}$ prior to treatment with adenosine for $24 \mathrm{~h}$.

$m R N A$ expression levels of CLCNKB in primary cultures of $m T A L$ cells. Several studies have confirmed that the mRNA expression of $C L C N K B$ is highest in the TAL of the loop of Henle and the distal convoluted tubule (24-26). In the present study, total RNA was isolated from primary cultures of mTAL cells, and the mRNA expression level of CLCNKB was detected using RT-qPCR analysis.

The mRNA expression of CLCNKB increased significantly following treatment with adenosine ( $\mathrm{P}<0.05$; Figs. 13 and 14). To determine whether the cAMP-PKA and PLA 2 -AA pathways affected the mRNA expression of $C L C N K B$ in the presence of adenosine, the cells were pretreated with $\mathrm{H} 8$ and AACOCF3 for $6 \mathrm{~h}$ and then stimulated with adenosine for $24 \mathrm{~h}$. It was found that $\mathrm{H} 8$ and AACOCF3 treatment inhibited the adenosine-induced changes in the mRNA expression of $C L C N K B$ (Figs. 15 and 16). Thus, it was concluded that adenosine affected the mRNA expression of CLCNKB through the cAMP-PKA and PLA ${ }_{2}$-AA pathways.

\section{Discussion}

The findings of the present study demonstrated that adenosine treatment increased the mRNA expression of $C L C N K B$ in the primary cultures of mTAL cells. Furthermore, it was found that the stimulatory effect of adenosine was mediated by the

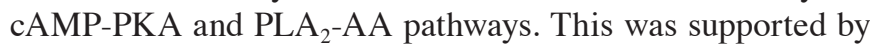
the observation that the inhibition of PKA and PLA $\mathrm{A}_{2}$ eliminated the stimulatory effect of adenosine on the mRNA expression of $C L C N K B$. The present study also found that adenosine treatment resulted in increased expression of PKA and decreased expression of $\mathrm{PLA}_{2}$. Sequential crosstalk was observed between these two pathways, in that adenosine first affected the mRNA expression of $C L C N K B$ through the cAMP-PKA pathway, followed by the PLA $\mathrm{A}_{2}$-AA pathway. These results led to the conclusion that the CAMP-PKA pathway was upstream of the PLA $\mathrm{PAA}_{2}$-A pathway. This was supported by the observation that adenosine stimulated the expression of PKA following inhibition of $\mathrm{PLA}_{2}$ with AACOCF3, but failed to affect the expression of $\mathrm{PLA}_{2}$ following inhibition of PKA with $\mathrm{H} 8$.

In the kidney, $\sim 20$ to $25 \%$ of the $\mathrm{Na}^{+}$and $\mathrm{Cl}^{-}$in the renal filtrate are actively reabsorbed. This indicates that the TAL is key in mediating the renal medulla hypertonic gradient, the concentration and dilution of urine, and salt capacity. Chloride channels are important anion channels in the human body (27), and $\mathrm{Cl}^{-}$transport is a crucial moderator of 
$\mathrm{Na}^{+}-2 \mathrm{Cl}^{-}-\mathrm{K}^{+}$cotransport. Utilizing patch-clamp and molecular biology techniques, six categories of chloride channels have been identified, and are encoded by several unrelated gene families (28). These include the CLC family, cystic fibrosis transmembrane conductance regulators (CFTRs), intracellular chloride channels (CLICs), calcium activated channels (CaCCs), volume-regulated anion channels (VRACs) and glycine or $\gamma$-GABA-activated chloride channels. CLCs, CFTRs, CaCCs and VRACs are chloride channels specific to the kidney (29). Using in situ hybridization and immunohistochemical staining, studies have confirmed that CLC-K2 is predominantly expressed in the basolateral mTAL of the rat kidney $(24-26,30)$. The human ortholog, $\mathrm{ClC}-\mathrm{Kb}$, which has $\sim 90 \%$ sequence homology and $\sim 80 \%$ homology with the rat ortholog (31), is also located in the basolateral mTAL, and is encoded for by $C L C N K B$, which has been listed as one of the candidate genes involved in hypertension $(32,33) . \mathrm{ClC}-\mathrm{Kb}$ is crucial, not only for the reabsorption of $\mathrm{Na}^{+}$and $\mathrm{Cl}^{-}$in the medullary and cortical portions of the distal tubule, but also in urine concentration, and in the establishment and maintenance of the corticomedullary osmotic gradient (34).

Previous studies have shown that the concentration of adenosine and mRNA expression of $C L C N K B$ increase when $\mathrm{NaCl}$ transport is upregulated, and that activation of the $\mathrm{ClC}-\mathrm{Kb}$ channel enhances $\mathrm{NaCl}$ transport $(35,36)$. A mutation in the $C L C N K B$ gene can result in Bartter syndrome type III, (predominantly from reduced reabsorption of $\mathrm{Na}^{+}$and $\mathrm{Cl}^{-}$in the TAL and distal convoluted tubule, and chronic hypotension) and salt-sensitive hypertension (35). These studies indicate that changes in chloride channel activity may be one of the factors affecting blood pressure. As already mentioned, adenosine is important in regulating kidney function through binding to adenosine receptors. There are four types of adenosine receptors: A1, A2a, A2b and A3 (37). Each of these is widely expressed in the kidney and it has been confirmed that the adenosine receptors have different binding affinities to adenosine (38). When the concentration of adenosine in the extracellular fluid is low ( $50-200 \mathrm{nM})(23)$, adenosine binds primarily to the A1 receptor. Under these conditions, kidney function is protected by the inhibition of $\mathrm{NaCl}$ transport in the TAL, and decreased consumption of energy and $\mathrm{O}_{2}$ (18). By contrast, under certain pathophysiological conditions, including ischemia and hypoxia, cells release an increased quantity of adenosine into the extracellular fluid $(>1 \mu \mathrm{M})(39,40)$. A high concentration of adenosine primarily binds to the $\mathrm{A}_{2}$ receptor, leading to the overtransportation of $\mathrm{NaCl}$ and overconsumption of $\mathrm{O}_{2}$ (18). Therefore, these pathophysiological conditions damage kidney function.

It has been previously established that the effects of adenosine are mediated by several pathways, including the cAMP-PKA and PLA $_{2}$-AA pathways $(37,41)$. A previous study also showed that a high-salt diet can increase the production of adenosine in mIMCD-K2 cells, and stimulate $\mathrm{Cl}^{-}$secretion by binding to the $\mathrm{A} 2$ receptor and activating the CFTR channel through the cAMP-PKA pathway (42). In addition, our previous study demonstrated that adenosine and its analog, N6-cyclohexyladenosine, enhance apical and basolateral potassium channel activity in the TAL through the cAMP-PKA pathway, which promotes $\mathrm{K}^{+}$outflow and regulates $\mathrm{Cl}^{-}$secretion (43-45). It was found that $5 \mu \mathrm{M}$ AA inhibits the activity of the $50 \mathrm{pS}$ potassium channel and the $10 \mathrm{pS}$ chloride channel, which are located in the basolateral mTAL. These effects were also achieved by 20-HETE, which is generated via the cytochrome P-450 monooxygenase pathway (46).

In conclusion, the data obtained in the present study showed the effects of adenosine on the mRNA expression of $C L C N K B$ in the basolateral mTAL of the rat kidney. As adenosine assists in the regulation of salt balance in the blood, it is a potential therapeutic target for certain diseases, including salt-sensitive hypertension. However, the results of the present study are limited as the mechanisms underlying the effect of adenosine on chloride channels remain to be fully elucidated. Therefore, additional investigations are required to assess the effects of adenosine on chloride channels and other channels under conditions of a high-salt diet.

\section{Acknowledgements}

This study was partially supported by a grant from the Chinese National Nature Science Foundations (grant nos. 31171110 and 31671196).

\section{References}

1. Bell PD, Lapointe JY, Sabirov R, Hayashi S, Peti-Peterdi J, Manabe K, Kovacs G and Okada Y: Macula densa cell signaling involves ATP release through a maxi anion channel. Proc Natl Acad Sci USA 100: 4322-4327, 2003.

2. Jackson EK, Mi Z, Gillespie DG and Dubey RK: Metabolism of cAMP to adenosine in the renal vasculature. J Pharmacol Exp Ther 283: 177-182, 1997.

3. Ward NC, Croft KD, Blacker D, Hankey GJ, Barden A, Mori TA, Puddey IB and Beer CD: Cytochrome P450 metabolites of arachidonic acid are elevated in stroke patients compared with healthy controls. Clin Sci (Lond) 121: 501-507, 2011.

4. Navar LG, Inscho EW, Majid SA, Imig JD, Harrison-Bernard LM and Mitchell KD: Paracrine regulation of the renal microcirculation. Physiol Rev 76: 425-536, 1996.

5. Navar LG, Harrison-Bernard LM, Nishiyama A and Kobori H: Regulation of intrarenal angiotensin II in hypertension. Hypertension 39: 316-322, 2002.

6. Schnermann J and Levine DZ: Paracrine factors in tubuloglomerular feedback: Adenosine, ATP, and nitric oxide. Annu Rev Physiol 65: 501-529, 2003.

7. Wilcox CS: Reactive oxygen species: Role in blood pressure and kidney function. Curr Hypertens Rep 4: 160-166, 2002.

8. Inscho EW: Modulation of renal microvascular function by adenosine. Am J Physiol Regul Integr Comp Physiol 285: R23-R25, 2003.

9. Fredholm BB: Adenosine, an endogenous distress signal, modulates tissue damage and repair. Cell Death Differ 14: 1315-1323, 2007.

10. Kinsey GR, Huang L, Jaworska K, Khutsishvili K, Becker DA, Ye H, Lobo PI and Okusa MD: Autocrine adenosine signaling promotes regulatory $\mathrm{T}$ cell-mediated renal protection. J Am Soc Nephrol 23: 1528-1537, 2012.

11. Kim SM, Mizel D, Huang YG, Briggs JP and Schnermann J: Adenosine as a mediator of macula densa-dependent inhibition of renin secretion. Am J Physiol Renal Physiol 290: F1016-F1023, 2006.

12. Schweda F, Wagner C, Krämer BK, Schnermann J and Kurtz A: Preserved macula densa-dependent renin secretion in A1 adenosine receptor knockout mice. Am J Physiol Renal Physiol 284: F770-F777, 2003.

13. Harris RC, Zhang MZ and Cheng HF: Cyclooxygenase- 2 and the renal renin-angiotensin system. Acta Physiol Scand 181: 543-547, 2004.

14. Hansen PB and Schnermann J: Vasoconstrictor and vasodilator effects of adenosine in the kidney. Am J Physiol Renal Physiol 285: F590-F599, 2003. 
15. Sun D, Samuelson LC, Yang T, Huang Y, Paliege A, Saunders T, Briggs J and Schnermann J: Mediation of tubuloglomerular feedback by adenosine: Evidence from mice lacking adenosine 1 receptors. Proc Natl Acad Sci USA 98: 9983-9988, 2001.

16. Carlström M, Wilcox CS and Welch WJ: Adenosine A2A receptor activation attenuates tubuloglomerular feedback responses by stimulation of endothelial nitric oxide synthase. Am J Physiol Renal Physiol 300: F457-F464, 2011.

17. Carroll MA, Doumad AB, Li J, Cheng MK, Falck JR and McGiff JC: Adenosine2A receptor vasodilation of rat preglomerular microvessels is mediated by EETs that activate the cAMP/PKA pathway. Am J Physiol Renal Physiol 291: F155-F161, 2006.

18. Di Sole F: Adenosine and renal tubular function. Curr Opin Nephrol Hypertens 17: 399-407, 2008.

19. Cheng MK, Doumad AB, Jiang H, Falck JR, McGiff JC and Carroll MA: Epoxyeicosatrienoic acids mediate adenosine-induced vasodilation in rat preglomerular microvessels (PGMV) via A2A receptors. Br J Pharmacol 141: 441-448, 2004.

20. Trinh-Trang-Tan MM, Bouby N, Coutaud C and Bankir L: Quick isolation of rat medullary thick ascending limbs. Enzymatic and metabolic characterization. Pflugers Arch 407: 228-234, 1986.

21. Hao S, Zhao H, Darzynkiewicz Z, Battula S and Ferreri NR Expression and function of NFAT5 in medullary thick ascending limb (mTAL) cells. Am J Physiol Renal Physiol 296: F1494-F1503, 2009.

22. Hao S, Zhao H, Darzynkiewicz Z, Battula S and Ferreri NR: Differential regulation of NFAT5 by NKCC2 isoforms in medullary thick ascending limb (mTAL) cells. Am J Physiol Renal Physiol 300: F966-F975, 2011.

23. Vallon V, Mühlbauer B and Osswald H: Adenosine and kidney function. Physiol Rev 86: 901-940, 2006.

24. Kobayashi K, Uchida S, Mizutani S, Sasaki S and Marumo F: Intrarenal and cellular localization of CLC-K2 protein in the mouse kidney. J Am Soc Nephrol 12: 1327-1334, 2001.

25. Adachi S, Uchida S, Ito H, Hata M, Hiroe M, Marumo F and Sasaki S: Two isoforms of a chloride channel predominantly expressed in thick ascending limb of Henle's loop and collecting ducts of rat kidney. J Biol Chem 269: 17677-17683, 1994.

26. Yoshikawa M, Uchida S, Yamauchi A, Miyai A, Tanaka Y, Sasaki S and Marumo F: Localization of rat CLC-K2 chloride channel mRNA in the kidney. Am J Physiol 276: F552-F558, 1999.

27. Zifarelli G and Pusch M: CLC chloride channels and transporters: A biophysical and physiological perspective. Rev Physiol Biochem Pharmacol 158: 23-76, 2007.

28. Li C and Naren AP: CFTR chloride channel in the apical compartments: Spatiotemporal coupling to its interacting partners. Integr Biol (Camb) 2: 161-177, 2010.

29. Uchida S and Sasaki S: Function of chloride channels in the kidney. Annu Rev Physiol 67: 759-778, 2005.

30. Tang CH, Hwang LY and Lee TH: Chloride channel ClC-3 in gills of the euryhaline teleost, Tetraodon nigroviridis: Expression, localization and the possible role of chloride absorption. J Exp Biol 213: 683-693, 2010.

31. Kieferle S, Fong P, Bens M, Vandewalle A and Jentsch TJ: Two highly homologous members of the $\mathrm{ClC}$ chloride channel family in both rat and human kidney. Proc Natl Acad Sci USA 91: 6943-6947, 1994.
32. Sile S, Gillani NB, Velez DR, Vanoye CG, Yu C, Byrne LM, Gainer JV, Brown NJ, Williams SM and George AL Jr: Functional BSND variants in essential hypertension. Am J Hypertens 20: 1176-1182, 2007.

33. Favero M, Calò LA, Schiavon F and Punzi L: Miscellaneous non-inflammatory musculoskeletal conditions. Bartter's and Gitelman's diseases. Best Pract Res Clin Rheumatol 25: 637-648, 2011.

34. Sile S, Velez DR, Gillani NB, Alexander CA, George AL Jr and Williams SM: Haplotype diversity in four genes (CLCNKA, CLCNKB, BSND, NEDD4 L) involved in renal salt reabsorption. Hum Hered 65: 33-46, 2008.

35. Krämer BK, Bergler T, Stoelcker B and Waldegger S: Mechanisms of disease: The kidney-specific chloride channels ClCKA and $\mathrm{ClCKB}$, the Barttin subunit, and their clinical relevance. Nat Clin Pract Nephrol 4: 38-46, 2008.

36. Capasso G, Rizzo M, Garavaglia ML, Trepiccione F, Zacchia M, Mugione A, Ferrari P, Paulmichl M, Lang F, Loffing J, et al: Upregulation of apical sodium-chloride cotransporter and basolateral chloride channels is responsible for the maintenance of salt-sensitive hypertension. Am J Physiol Renal Physiol 295: F556-F567, 2008.

37. Schulte $G$ and Fredholm BB: Human adenosine A(1), A(2A), $\mathrm{A}(2 \mathrm{~B})$, and $\mathrm{A}(3)$ receptors expressed in Chinese hamster ovary cells all mediate the phosphorylation of extracellular-regulated kinase 1/2. Mol Pharmacol 58: 477-482, 2000.

38. Yaar R, Jones MR, Chen JF and Ravid K: Animal models for the study of adenosine receptor function. J Cell Physiol 202: 9-20, 2005.

39. Nishiyama A, Kimura S, He H, Miura K, Rahman M, Fujisawa Y, Fukui T and Abe Y: Renal interstitial adenosine metabolism during ischemia in dogs. Am J Physiol Renal Physiol 280: F231-F238, 2001.

40. Latini S, Bordoni F, Pedata F and Corradetti R: Extracellular adenosine concentrations during in vitro ischaemia in rat hippocampal slices. Br J Pharmacol 127: 729-739, 1999.

41. Sexl V, Mancusi G, Höller C, Gloria-Maercker E, Schütz W and Freissmuth M: Stimulation of the mitogen-activated protein kinase via the A2A-adenosine receptor in primary human endothelial cells. J Biol Chem 272: 5792-5799, 1997.

42. Rajagopal M and Pao AC: Adenosine activates a2b receptors and enhances chloride secretion in kidney inner medullary collecting duct cells. Hypertension 55: 1123-1128, 2010.

43. Gu R, Wang J, Zhang Y, Li W, Xu Y, Shan H, Wang WH and Yang B: Adenosine stimulates the basolateral $50 \mathrm{pS} \mathrm{K}$ channels in the thick ascending limb of the rat kidney. Am J Physiol Renal Physiol 293: F299-F305, 2007.

44. Li D, Wei Y and Wang WH: Dietary K intake regulates the response of apical $\mathrm{K}$ channels to adenosine in the thick ascending limb. Am J Physiol Renal Physiol 287: F954-F959, 2004.

45. Wang M, Sui H, Li W, Wang J, Liu Y, Gu L, Wang WH and Gu R: Stimulation of $\mathrm{A}\left({ }_{2} \mathrm{a}\right)$ adenosine receptor abolishes the inhibitory effect of arachidonic acid on the basolateral 50-pS K channel in the thick ascending limb. Am J Physiol Renal Physiol 300: F906-F913, 2011.

46. Gu RM, Yang L, Zhang Y, Wang L, Kong S, Zhang C, Zhai Y, Wang M, Wu P, Liu L, et al: CYP-omega-hydroxylation-dependent metabolites of arachidonic acid inhibit the basolateral $10 \mathrm{pS}$ chloride channel in the rat thick ascending limb. Kidney Int 76: 849-856, 2009 